\title{
DUKUNGAN SOSIAL TEMAN SEBAYA TERHADAP PERILAKU BULLYING
}

\author{
Wahyu Bagja Sulfemi ${ }^{1}$, Okti Yasita ${ }^{2}$ \\ 1 STKIP Muhammadiyah Bogor \\ 2 STIKes Wijaya Husada Bogor \\ e-mail: \\ wahyubagja@gmail.com, Oktiyasita1010@gmail.com
}

\begin{abstract}
Abstrak: Deskriptif analitis kuantitatif dengan pendekatan cross sectional yang digunakan dalam kajian ini. Penelitian ini dilakukan di SMA Taruna Andhiga Kota Bogor yang terdiri dari 110 orang dengan jumlah sampel sebanyak 86 orang secara random sampling. Latar belakang dari studi ini adalah maraknya perilaku bullying di Kota Bogor dimana 30\% sampai $40 \%$ pelajar menjadi korban bullying. Berdasarkan analisi data diketahui terdapat 36 orang atau (41.9) dukungan sosial teman sebaya negatif dan 50 orang atau $(58.1 \%)$ memberikan dukungan positif. Terdapat 45 orang $(52,3 \%)$ berperilaku bullying dan 41 orang $(47,7 \%)$ tidak berperilaku bullying. Terdapat hubungan signifikan antara dukungan sosial teman dengan perilaku bullying dengan risiko pencegahan sebesar 0,258 kali lipat dibandingkan yang tidak mendapat dukungan sosial.
\end{abstract}

Kata kunci: dukungan sosial,teman sebaya, dan perilaku bullying, perundungan

\section{INTERACTION OF PEER'S SOSIAL SUPPORT AND BULLYING BEHAVIOR}

\begin{abstract}
Descriptive quantitative analytic with a cross-sectional approach was used in this study. This research was conducted at SMA Taruna Andhiga Bogor City, amounting to 110 people with a sample size of 86 people by random sampling. The background of this research is the rampant bullying behavior in Bogor City where 30\% to $40 \%$ of students are victims of bullying. Based on the results of data analysis, it is known that there are 36 people or (41.9) negative peer social support, and 50 people or (58.1\%) provide positive support. There were 45 people (52.3\%) who behaved bullying and 41 people (47.7\%) did not behave bullying. There is a significant relationship between social support from friends and bullying behavior with a risk of 0.258 times compared to those who do not have social support.
\end{abstract}

Keywords: social support, peers, bullying behavior 


\section{PENDAHULUAN}

Fase remaja adalah peralihan dari masa anak-anak menjadi orang dewasa sejalan dengan perkembangan dan pertumbuhan pada manusia. Terdapat tiga kelompok usia remaja, yaitu: Masa awal, rentang umur 12 tahun sampai umur 15 tahun; Masa tengah-tengah, rentang usia antara 15 sampai dengan usia 18 tahun; Masa remaja akhir, yaitu rentang umur 18 sampai dengan usia 21 tahun (Febri \& Nuristighfari, 2014). Masa remaja dalam perkembangnya mengalami perubahan pada berbagai aspek kejiwaan remaja, seperti kecerdasan intelektual, emosi dan mental. Hal ini dipengaruhi oleh faktor ekstrinsik seperti stres atau ketegangan akan harapan baru, yang dapat berdampak pada melakukan kenakalan (Santrock, 2012). Selanjutnya Paramitasari, (2012) menyampaikan bahwa ketika usia remaja sering mengalami kesulitan untuk mengontrol atau menguasai emosi. Dengan memahami dan menguasai gejolak emosinya para remaja mampu menyesuaikan diri dengan keadaan dilingkungan dimana meraka berada.

Berdasarkan data dari Kementerian Kesehatan disebutkan bahwa 1,2 milyar penduduk atau $18 \%$ penduduk dunia adalah remaja, sedangkan di Negara Indonesia tahun 2014 terdapat 65 juta jiwa atau 25\% remaja. Data tersebut menunjukkan bahwa jumlah penduduk usia remaja cukup besar (Kemenkes. 2014). Usia pada masa remaja ini merupakan usia dimana seseorang mengikuti pendidikan di sekolah. Para remaja bersekolah dengan harapan mendapat pembinaan pendidikan yang berdasarkan kepada kepercayaan dan tuntutan lingkungan keluarga dan masyarakat dengan adanya perubahan tingkah laku dari peserta didik yang secara disadari dan dilihat dari segi fungsinya secara positif (Sulfemi, 2018). Akan tetapi, pada masa remaja ini lah sering terjadi perilkau bullying yaitu aksi secara agresif tertentu yang dapat menyebabkan terjadinya kerusakan atau kehancuran secara kontinyu, dan menyebabkan hilangnya ketidakseimbangan kekuatan (Nini, 2016).

Membicarakan masalah bullying tidak pernah habis dari waktu ke waktu, perilaku ini menjadi fenomena yang semakin mengkhawatirkan dan menjadi sorotan pemerintah dan masyarakat. Perilaku menyimpang bullying adalah masalah yang selalu ada setiap tahunnya seakan tidak pernah berhenti. Darmawan, (2017) dan Afroz, (2015) menjelaskan bahwa bullying berasal dari kata bully dari bahasa Inggris. Istilah bullying pertama kali dikenal di negara-negara Barat khususnya di Eropa tetapi pada perkembangannya kata ini digunakan di seluruh dunia. Permasalahan mengenai bullying pertama kali diteliti oleh seorang profesor bernama Dan Olweus seorang warga negara Swedia. Kata Bullying di Indonesia lebih dikenal dengan kata "perundungan". Kata ini berasal dari kata dasar "rundung" yang memiliki makna sulit atau susah. Selanjutnya setelah diberikan imbuhan "pe" dan "an" menjadi nomina komplit yaitu "perundungan" yang memiliki arti mengganggu, penimpaan, dan penyusahan atau suatu tindakan kekerasan yang dilakukan terus menerus. Kata "perundungan"sekarang sudah dibakukan tetapi kata bullying lebih sering digunakan di masyarakat. Lebih lanjut Amalia, et al. (2019) menyampaikan bahwa kata bullying atau perundungan merupakan sebuah aksi teror berupa mengucilkan, intimidasi, kekerasan secara fisik dan mental, serta perpeloncoan. 
Papacosta, Paradeisioti \& Lazarou, (2014) menyampaikan bahwa bullying merupakan pemaksaan secara fisik maupun verbal, melakukan dan menyebarkan penyebaran desas-desus palsu, serta pengucilan sosial dengan menggunakan media dari internet ataupun telepon seluler dengan mengirimkan pesan-pesan jahat yang dilakukan secara berulangkali terhadap korban. Hubungan antara pem-bully dan korban didasarkan pada masalah kekuasaan. Yusuf \& Fahrudin (2012) menambahkan bahwa para pem-bully bertindak dengan sengaja untuk membahayakan dan menyakiti para korban demi mencapai kepuasan pelaku bully. Berbagai kelemahan dari ini korban dijadikan dasar para pem-bully untuk melecehkan korbannya baik secara fisik, psikologis dan verbal. Indri \& Layyinah, (2016) menambahkan bahwa para pelaku bullying memiliki keinginan yang kuat untuk melukai sehingga korbannya menjadi tertekan. Heryana, (2019) menambahkan bullying adalah menggertak orang yang lemah terutama dari segi fisik.

Selanjutnya Darmayanti, et al, (2019) menjelaskan bahwa sikap atau perilaku kekerasan yang dilakukan di kelas atau sekolah oleh peserta didik disebut dengan school bullying, kasus ini banyak terjadi di sekolah SMP dan SMA. Manesini \& Salmivalli (2017) menjelaskan ciri-ciri bullying di sekolah yaitu tindakan kekerasan yang dilakukan bersama-sama berdasarkan hubungan dalam kelompok yang dilakukan dengan sengaja dan secara terus menerus untuk melemahkan, melumpuhkan, dan mempermalukan korbannya. Kasus bullying di sekolah yang paling banyak dilakukan para peserta didik adalah kasus senioritas yaitu intimidasi dari kakak kelasnya terhadap adik kelasnya. Beberapa contoh bully yang terjadi di sekolah, seperti: Meminta dibelikan makanan dan minuman, serta meminta jawaban ketika ulangan. Kasus lainnya, yaitu berupa memberikan nama samaran atau julukkan yang tidak menyenangkan sehingga diejek teman-temannya yang lain. Ejekan ini sampai membuat korbannya menangis dan menjadi bahan tertawaan (Sulfemi, 2019).

Ribakova \& Valeeva, (2016) menjelaskan bahwa terdapat beberapa faktor penyebab terjadinya bullying pada peserta didik, yaitu: 1) Keluarga; 2) Sekolah; 3) Kelompok sebaya; 4) Kondisi lingkungan sosial dan; 5) Tayangan televisi, internet, media sosial dan media cetak. Berikut beberapa jenis bullying pada para pelajar, yaitu: 1) Secara fisik; 2) Secara verbal; 3) Relasional; dan 4) Cyber bullying. Menurut Smith, (2013) cyber bullying adalah salah satu bentuk bullying yang terbaru karena pengaruh berkembangnya teknologi, internet, dan media sosial.

Hasil kajian Junior Chamber International (JCl) menyampaikan bahwa hampir sekitar $40 \%$ peserta didik yang berada di Kota Bogor menjadi korban perilaku bullying. Para korban ini kebanyakan adalah para pelajar Sekolah Menengah Pertama (SMP) dan Sekolah Menengah Atas (SMA) sekitar 30\% sampai 40\% (Pebriansyah, 2016). Selanjunya hasil penelitian dari Fenti \& Nurdiana (2019) menyampaikan bahwa terjadi 87 kasus bullying, dimana terdapat 36 korban dan 51 pelaku kekerasan.

Seorang anak yang memiliki kekurangan fisik dan mental sering menjadi korban bullying. Sementara itu, psikiater anak dan remaja menyampaikan akibat dari perilaku bullying pada anak bisa berbeda-beda tergantung pada respon terhadap tindakan bully serta kemampuan mentalnya (Dara, 2018). Di Negara 
Amerika, berdasarkan data statistik terdapat $28 \%$ peserta didik kelas enam sampai kelas dua belas yang pernah mengalami perilaku perundungan atau bullying, $30 \%$ pernah melakukan bullying, dan $70 \%$ staf sekolah melihat para peserta didik melakukan bullying (Lagmin, 2016).

Masalah atau kasus bullying di sekolah menempati peringkat pertama dalam pengaduan dari masyarakat ke Komisi Perlindungan Anak Indonesia (KPAl), dengan 369 kasus sejak tahun 2011 sampai tahun 2014 (Kandi, 2016). Hasil dari klaster pengaduan ke KPAI pada masa Januari 2011, sampai Juli 2015 menyampaikan 5 (lima) katagori pengaduan dan salah satu katagorinya mengenai kekerasan di sekolah dimana anak yang menjadi korban mencapai 496 orang. Anak sekolah yang melakukan tawuran berjumlah 325 orang pelajar, 283 orang pelajar tercacatat melakukan kekerasan di sekolah, dan 271 perserta didik menjadi korban tawuran antar pelajar (Muthia, 2017).

Semakin maraknya perilaku bullying antar pelajar yang terjadi di sekolah tidak terlepas dari tingkat emosional peserta didik pada tingkat remaja yang masih labil, salah satunya adalah bentuk emosi yang diidentifikasikan sebagai amarah. Amarah yang ada pada dirinya mengakibatkan seorang remaja mengamuk, melakukan tindakan brutal, kesal atau jengkel, tersinggung, benci, kesal hati, bermusuhan, dan melakukan tindak kekerasan (Irnie, 2017). Data hasil dari kajian Konsorsium Nasional Pengembangan Sekolah Karakter yang dilakukan pada tahun 2014 menyampaikan bahwa di setiap sekolah atau lembaga pendidikan di Indonesia terdapat kasus bullying, tetapi berupa bullying verbal atau psikologis (Sulfemi, 2019).

Tindakan kekerasan yang dilakukan para pelajar menjadi permasalahan yang cukup serius baik yang dilakukan perseorangan maupun secara kelompok (Latifah, 2012). Perilaku menyimpang bullying dipengaruhi oleh pergaulan dengan teman-teman seumuran atau sebaya (Karina, et al, 2013). Memang harus diakui bahwa manusia tidak bisa hidup sendiri dan akan berkelompok untuk saling berinteraksi, demikian pula remaja yang bergaul dengan teman-teman seumurannya. Akan tetapi, permasalahannya para teman di kelompoknya tersebut dapat mempengaruhi seorang peserta didik untuk melakukan tindakan yang melanggar aturan dan tidak disiplin agar dapat diakui dalam kelompoknya. Pengaruh atau dukungan sosial dari kelompok ini menjadi pemicu banyak terjadinya bullying di sekolah. Aisyiah, (2017) menyampaikan bahwa dukungan sosial merupakan sebuah informasi atau umpan balik dari sorang lain yang menunjukan bahwa seseorang itu dihargai dicintai dihormati, dilibatkan, dan diperhatikan oleh masyarakat dalam komunikasi secara terarah.

Hasil penelitian dari Latifah, (2012) menunjukkan bahwa 65 persen anak pernah mengalami bullying. Kajian dari Karina, (2013) menunjukkan bahwa lebih dari tiga per lima remaja laki-laki, 66 persen, dan sebagian besar remaja perempuan, $8 \%$ merupakan seorang pelaku bullying. Sementara itu, $22 \%$ remaja laki-laki dan 8,0\% perempuan menemani temannya melakukan bullying. Selain itu, diketahui pula $12,0 \%$ laki-laki dan $6,0 \%$ perempuan merupakan pelaku bullying. Hasil penelitian dari Setiawan (2015) menunjukkan adanya pengaruh yang signifikan antara dukungan sosial teman sebaya terhadap tindakan agresif peserta didik sebesar 31,6 persen sedangkan 68,4 persennya dipengaruhi oleh faktor-faktor 
lainnya. Berdasarkan kajian ini dapat disimpulkan bahwa teman sebaya mempengaruhi agresivitas peserta didik.

Dari hasil study pendahuluan di SMA Taruna Andhiga Kota Bogor dengan sepuluh orang sampel dari kelas $X$ diperoleh enam orang mengungkapkan suka memprovokasi teman-temannya, empat lainnya saling mendukung untuk memprovokasi. Empat dari sepuluh anak mengungkapkan suka mengejek jika mengejek ada kepuasan tersendiri dan enam anak lainnya setuju, jika mengejek ada kepuasan tersendiri. Tiga dari sepuluh anak akan mengucilkan temannya jika berbuat salah, dua lainnya mendukung untuk mengucilkan teman yang berbuat salah, lima lainnya tidak setuju untuk melakukan hal tersebut. Tiga dari sepuluh anak menggunakan kekerasan pada temannya jika sedang bertengkar, lima anak lainnya mendukung untuk menggunakan kekerasan, dua lainnya menolak untuk melakukan hal tersebut. Delapan dari sepuluh anak suka meneriaki, menjahili, dan mencibir anak yang lemah, dua lainnya mendukung temannya untuk melakukan hal tersebut.

Delapan dari sepuluh anak merasa khawatir menceritakan masalahnya kepada temannya, dua lainnya merasa tidak keberatan untuk menceritakan masalahnya. Lima dari sepuluh anak memilih teman dalam bergaul, sementara lima lainnya memilih untuk berbaur dengan teman yang lain. Enam dari sepuluh anak memilih tidak perduli jika temannya melanggar peraturan, empat lainnya memperhatikan temannya jika melanggar peraturan. Tujuh dari sepuluh anak selalu mencela temannya jika melakukan kesalahan, tiga lainnya mendukung temannya untuk ikut mencela.

Kasus bullying ini seharusnya tidak terjadi di sekolah, dimana sekolah merupakan sarana pengembangan bakat dan kreativitas, pusat pengembangan, pemberdayaan dan pembudayaan sepanjang hayat, serta tempat mengembangkan kemampuan peserta didik (Palettei \& Sulfemi, 2019). Sekolah harus menjadi sebuah tempat kumpulan orang-orang yang memberikan penghormatan dan pengakuan terhadap hak dan kewajiban setiap setiap individu yang menciptakan berkeberadaban serta keharmonisan menuju masyarakat yang adil dan tertib (Hidayat, 2007). Melihat ini maka masyarakat dan sekolah termasuk guru berkewajiban untuk untuk bertanggungjawab dengan perilaku yang menyimpang para peserta didik (Sulfemi, \& Yuliana, 2019).

Maraknya perilaku bullying dikalangan pelajar perlu dilakukan kajian lebih lanjut, maka untuk itu dilakukan studi yang mengkaji bagaimana dukungan sosial teman sebaya dengan perilaku bullying terutama di SMA Taruna Andhiga Kota Bogor. Dengan adanya kajian ini dapat menambah informasi bagi peserta didik khususnya mengenai perilaku bullying di sekolah dan sebagai bahan informasi agar setiap sekolah dapat meningkatkan program anti bullying yang tepat bagi peserta didik dalam lingkungan sekolah maupun luar.

\section{METODE}

Dalam kajian ini dipilih metode deskriptif analitik kuantitatif dengan menggunakan cross sectional data untuk menggambarkan dukungan sosial teman sebaya (variabel independent) terhadap tindakan bullying (variabel dependen) dengan populasi yaitu seluruh peserta didik kelas 11 dan 12 SMA Taruna Andhiga 
Bogor yang berjumlah 110 responden. Untuk mencari besaran sampel digunakan rumus slovin yaitu: $n=\frac{N e}{1+N(d)^{2}}=\frac{110}{1+110(0,05)^{2}}=86,27$ dibulatkan menjadi 86 orang dengan simple random sampling (Silalahi, 2015).

Untuk mengukur variabel bebas $(X)$ dukungan sosial teman sebaya menggunakan 40 pertanyaan kuesioner yang terdiri dari 20 soal positif dan 20 soal negatif. Dukungan sosial sosial teman sebaya yang diartikan sebagai suatu hubungan yang bersifat menolong atau mempengaruhi kesejahteraan individu yang bersifat tindakan atau informasi yang didapatkan dari orang-orang terdekat (Nini, 2016). Berdasarkan teori tersebut maka definisi operasional variabel ini sebagai berikut:

Tabel 1. Intrumen Dukungan Sosial Teman Sebaya

\begin{tabular}{llccc}
\hline \multicolumn{1}{c}{ Variabel } & \multicolumn{1}{c}{ Indikator } & Positif & Negatif & Jumlah \\
\hline Dukungan & Appraisal support & $1,2,3$ & $4,5,39$ & 6 \\
Sosial & Tangible support & $6,7,8$ & 9,10 & 5 \\
Teman & Self esteem support & $11,12,13$ & $14,15,16$ & 6 \\
Sebaya & Belonging support & $17,18,19$ & $20,21,40$ & 6 \\
& Bantuan yang nyata & $22,23,24$ & 25,26 & 5 \\
& Informasi & $27,28,29$ & $30,31,38$ & 6 \\
& Dukungan emosional & $32,33,34$ & $35,36,37$ & 6 \\
\hline & Jumlah & 20 & 20 & 40 \\
\hline
\end{tabular}

Untuk jawaban positif jika responden menjawab "ya" diberikan nilai 1 dan menjawab "tidak" diberi nilai 0 . Untuk jawaban negatif jika responden menjawab "ya" maka diberi nilai 0 , sedangkan jika menjawab "tidak" diberi nilai 1 . Berikut beberapa contoh soal yang disajikan untuk variabel dukungan sosial teman sebaya: Apakah teman anda selalu mencela jika anda melakukan suatu kesalahan? Apakah teman sebaya anda pernah mengucilkan anda di kelas? Apakah teman anda merasa senang jika mengikuti apa yang anda lakukan? Selanjutnya hasil jawaban responden atau peserta didik ini diukur dengan menggunakan skala Guttman.

Variabel perilaku bullying berdasarkan definisi operasional perilaku bullying yaitu sebuah tindakan baik secara individu maupun kelompok berupa aksi teror untuk mengucilkan, intimidasi, dan perpeloncoan baik secara fisik, verbal, relasional, maupun media sosial (Afroz, 2015), dari definisi operasional tersebut maka digunakan matriks intrumen penelitian perilaku bullying sebagai berikut.

Tabel 2. Intrumen Perilaku Bullying

\begin{tabular}{clccc}
\hline \multirow{2}{*}{ Variabel } & \multicolumn{1}{c}{ Indikator } & \multicolumn{2}{c}{ Jawaban } & \multirow{2}{*}{ Positif } \\
\cline { 3 - 5 } & & $1,3,4$ & Negatif & \\
\hline Perilaku & Pemahaman bullying & $2,5,6$ & 6 \\
bullying & Bullying fisik & $8,9,13,14$ & $7,10,11,12,15,16$, & 10 \\
& Bullying verbal & $17,20,35,36,37$ & $18,19,38,39,40$ & 10 \\
& Bullying relasional & $21,23,25,27,30$, & $22,24,29,33$ & 9 \\
& Cyber bullying & $31,32,34$ & 26,28 & 5 \\
\hline & Jumlah & 20 & 20 & 40 \\
\hline
\end{tabular}


Jawabahan dari responden diukur mengunakan skala Likert dengan skala1-4. Untuk variabel tidak berperilaku bullying atau bullying positif dengan penskoran sebagai berikut: 4 = sangat setuju, 3 = setuju, 2 = tidak setuju, dan $1=$ sangat tidak setuju. Sedangkan untuk berperilaku bullying atau bullying negative, yaitu: poin 1 = sangat tidak sesuai, 2 = tidak sesuai, 3 = sesuai, 4 = sangat sesuai (Sugiyono. 2010). Pengukuran pengkategorian menggunakan mean yaitu perilaku negatif jika nilai $T$ skor $<T$ mean, dan perilaku positif jika nilai $T$ skor $\geq T$ mean. Beberapa contoh soal yang digunakan dalam kajian ini seperti: Saya tidak segan memukul teman yang berbuat salah kepada saya, saya tidak tega memukul orang walaupun saya dijelek-jelekkan, dan saya suka memalak teman saya.

Untuk mengukur korelasi tiap-tiap item pertanyaan dengan skors total maka dilakukan uji validitas dengan menggunakan korelasi Pearson Product Moment (Saifuddin, 2007). Untuk mendapatkan nilai yang signifikan, maka dilakukan uji korelasi dengan membandingkan $r$ hitung dan $r$ tabel dengan uji $t$. Selanjutnya untuk melihat alat pengukuran dapat dipercaya maka dilakukan uji reliabilitas dengan uji cronbach alpha. Bila hasil dari uji cronbach alpha $(>0,60)$ dari $r$ tabel artinya variabel tersebut reliabel, dan bila cronbach alpha $(<0,60)$ varibel tidak reliable (Septiyuni, 2018).

Pada hasil data yang telah dikumpulkan selanjutnya dilakukan pengolahan data dengan meggunakan: Editing (penyunting data), coding (pengkodean), tabulasi (tabulating) dan cleaning data. Untuk menjawab tujuan penelitian mengenai pengaruh dukungan sosial teman sebaya dan perilaku bullying secara menyeluruh dilakukan dengan menggunakan analisis regresi linearitas sederhana. Selanjutnya untuk menjelaskan variabel data dibuat dalam tabel distribusi frekuensi yang dianalisa menggunakan analisis univariat.

Untuk menganalisa hubungan antar variabel digunakan analisa bivariat dengan uji analisis Chi-Square digunakan untuk menguji hipotesis komparatif. Sedangkan untuk memutuskan apakah terdapat hubungan antara variabel dependent dan variabel independent, maka digunakan $p$ value yang dibandingkan dengan tingkat kesalahan (alpha) yaitu $5 \%$ atau 0,05 . Apabila $p$ value $\leq 0,05$, maka $\mathrm{Ho}$ ditolak dan $\mathrm{Ha}$ (hipotesis penelitian) diterima, yang berarti ada hubungan antara variabel dependent dan variabel independent. Apabila $p$ value $>0,05$, maka $\mathrm{Ho}$ diterima dan $\mathrm{Ha}$ (hipotesis penelitian) ditolak yang berarti tidak ada hubungan antara variabel dependent dan variabel independent. Untuk mengetahui terdapat hubungan atau tidaknya nilai signifikansi indek dari setiap variabel, maka digunakan uji Koefisien Crammer's V (Puspita, 2018; Widarsa, et al. 2016). Selanjutnya untuk menganalisis mengukur hubungan antara paparan setiap variabel dan dibandingkan dengan kemungkinan hasil yang terjadi dari paparan variabel tersebut digunakan parameter Odd Ratio (OR) (Karnowahadi, 2017; Nadi, 2018). Perhitungan data dalam penelitian ini menggunakan SPSS (Statistical Package for the Social Science).

\section{HASIL DAN PEMBAHASAN}

SMA Taruna Andhiga Kota Bogor merupakan tempat studi ini dilakukan dengan jumlah reponden sebanyak 86 orang peserta didik kelas XI dan XII. Alat ukur yang digunakan adalah kuesioner. Kajian ini bertujuan untuk mengetahui 
hubungan variabel yang diteliti yaitu dukungan sosial teman sebaya (variabel independen) serta perilaku bullying (variabel dependen).

Untuk mengukur validitas pertanyaan kuesioner maka dilakukan uji validitas, dengan sampel 20 orang responden. Hasil uji validitas dari dukungan sosial teman sebaya dari 40 pernyataan didapatkan 40 pernyataan valid dimana $r$ hitung $>0,444$. Sementara untuk variabel perilaku bullying dari 40 pernyataan didapatkan 40 pernyataan valid. Selanjutnya instrumen digunakan untuk pengumpulan data menggunakan jumlah responden sebanyak 86 dengan usia antara 15 sampai umur 17 tahun. Untuk karakteristik subjek berdasarkan jenis kelamin diperoleh responden perempuan sebanyak 49 orang atau $57 \%$ dan responden peserta didik laki-laki 37 orang atau $43 \%$. Sehingga responden dengan jenis kelamin perempuan memiliki distribusi terbanyak yaitu 49 orang atau $57,0 \%$.

Variabel dukungan sosial teman sebaya diartikan sebagai informasi atau umpan balik dari orang lain yang menunjukan bahwa seseorang dicintai dan diperhatikan, dihargai, dihormati, serta dilibatkan dalam jaringan komunikasi dan kewajiban yang timbal balik (King, 2010). Rokhmatika \& Darminto (2013) menyampaikan bahwa dukungan sosial positif adalah apabila seorang individu memiliki anggapan bahwa dukungan sosial yang diterimanya dari orang lain sesuai dengan kebutuhan yang ada pada dirinya, sehingga dapat menjadi sarana coping stres ketika memiliki masalah, dan dapat membuat lebih mampu menyesuaian diri dengan berbagai kesulitan dan tantangan. Sari \& Indrawati (2016) juga menjelaskan bahwa dukungan teman sebaya yang dipersepsikan peserta didik secara positif dapat mempengaruhi peserta didik untuk merasa mampu bangkit kembali ketika mendapat permasalahan dan optimis untuk menghadapi permasalahan yang dialaminya. Dukungan sosial negatif seperti yang disampaikan Desmita, (2010) yaitu dukungan tidak membantu, dukungan yang tidak sesuai keinginan atau kebutuhan, dan sumber dukungan memberikan contoh buruk pada individu lain. Lebih lanjut Puspita, (2018) menjelaskan dukungan sosial teman sebaya yang tinggi dapat mendukung remaja untuk tidak berperilaku negatif, sebaliknya dukungan teman sebaya yang rendah akan mendorong individu untuk melakukan perilaku negatif.

Hasil penelitian menunjukkan distribusi frekuensi variabel dukungan sosial teman sebaya sebagaimana pada Tabel 3.

Tabel 3. Distribusi Frekuensi Dukungan Sosial Teman Sebaya

\begin{tabular}{ccc}
\hline Kategori & \multicolumn{2}{c}{ Total } \\
\hline & $\mathrm{N}$ & $\%$ \\
\hline Dukungan Sosial Negatif & 36 & 41.9 \\
Dukungan Sosial Positif & 50 & 58.1 \\
\hline Total & 86 & 100 \\
\hline
\end{tabular}

Berdasarkan data pada Tabel 3 , dari 86 orang responden diperoleh distribusi frekuensi dukungan sosial teman sebaya negatif sebanyak 36 orang atau 41.9 persen, sedangkan dukungan sosial teman sebaya positif sebanyak 50 orang atau 58.1 persen. Dengan demikian, bahwa peserta didik di SMA Taruna Andhiga lebih banyak yang memberikan dukungan secara positif atau yang baik akan 
keinginan dan kebutuhan kepada teman-temannya dalam bersosialisasi sehingga merasa diterima, dihargai, mampu mengontrol diri dalam berperilaku dan memberikan contoh yang baik, dibandingkan yang memberikan dukungan sosial secara negatif atau sebagai sumber dukungan memberikan contoh buruk kepada teman yang lain.

Berkenaan dengan perilaku bullying, seperti yang disampaikan oleh Saifullah (2016) bahwa tindakan berkali-kali meneror, mengucilkan, intimidasi, dan perpeloncoan baik secara fisik, verbal, relasional, maupun media sosial baik secara perseorangan ataupun kelompok terhadap peserta didik lain yang lebih junior atau lebih lemah ini maka ini disebut perilaku bullying negatif. Akan tetapi, jika sebaliknya tidak melakukan perilaku bullying ini maka akan berperilaku positif. Berdasarkan data yang diperoleh peserta didik yang berperilaku bullying sebanyak 45 orang atau 52,3 persen sedangkan yang tidak melakukan perilaku bullying terdapat 41 orang responden atau 47,7 persen. Berdasarkan jenis kelamin responden perempuan yang berjumlah 49 orang diketahui 26 orang peserta didik atau $53.1 \%$ pelaku bullying dan 23 orang atau $46.9 \%$ tidak berperilaku bullying. Untuk responden laki-laki yang berjumlah 37 orang responden diperoleh 18 orang atau $48.6 \%$ pelaku bullying dan 19 orang atau $51.4 \%$ tidak berperilaku bullying. Dengan demikian responden perempuan cenderung berperilaku bullying dibanding responden laki-laki yang cenderung tidak berperilaku bullying. Berikut tabel distribusi frekuensi perilaku bullying di SMA Taruna Andhiga Bogor.

Tabel 4. Distribusi Frekuensi Perilaku Bullying

\begin{tabular}{ccc}
\hline \multirow{2}{*}{ Kategori } & \multicolumn{2}{c}{ Total } \\
\cline { 2 - 3 } & $\mathbf{N}$ & $\%$ \\
\hline Berperilaku bullying & 45 & 52,3 \\
Tidak berperilaku bullying & 41 & 47,7 \\
\hline Total & 86 & 100 \\
\hline
\end{tabular}

Dari data pada Tabel 4 dapat disimpulkan bahwa dari 86 orang responden, distribusi terbanyak pada kategori berperilaku bullying, yaitu sebanyak 45 peserta didik atau 52,3\%, artinya peserta didik di SMA Taruna Andhiga Bogor mempunyai kecenderungan melakukan tindakan bullying terhadap peserta didik lain dibandingkan yang tidak berperilaku bullying yaitu 41 orang atau 47.7 persen

Selanjutnya pada data variabel dukungan sosial teman sebaya dan variabel perilaku bullying tersebut dilakukan analisa bivariat dengan menggunakan SPSS. Hasil analisa bivariat sebagaimana pada Tabel 5.

Berdasarkan data Tabel 3, dari 86 responden diketahui bahwa dari 36 orang peserta didik atau 41, 9 persen yang mendapat dukungan sosial teman sebaya secara negatif dimana 12 orang atau $14.0 \%$ berperilaku bullying dan sebanyak 24 orang peserta didik atau $27.9 \%$ tidak berperilaku bullying. Artinya bahwa walaupun perserta didik yang mendapat dukungan sosial secara negatif dari kawan-kawan tetapi peserta dididk SMA Taruna Andhga tidak melakukan perilaku bullying. Peserta didik yang mendapat dukungan sosial teman sebaya positif terdapat 50 orang peserta didik atau $58.1 \%$, dimana 33 orang peserta didik atau $38.4 \%$ melakukan perilaku bullying, sedangkan 17 orang peserta didik atau $19.8 \%$ 
tidak melakukan perilaku bullying. Artinya bahwa walaupun mendapat dukungan sosial dari temannya secara positif tetapi peserta didik di SMA Taruna Andiga lebih banyak yang berperilaku bullying.

Tabel 5. Hubungan Antara Dukungan Sosial Teman Sebaya dengan Perilaku

\begin{tabular}{|c|c|c|c|c|c|c|c|}
\hline & & & \multicolumn{2}{|c|}{ Perilaku_Bullying } & \multirow[b]{2}{*}{ Total } & \multirow{2}{*}{$\begin{array}{c}\text { OR } \\
95 \% \mathrm{Cl}\end{array}$} & \multirow{2}{*}{$\begin{array}{c}P \\
\text { value }\end{array}$} \\
\hline & & & $\begin{array}{c}\text { Berperilaku } \\
\text { bullying }\end{array}$ & $\begin{array}{c}\text { Tidak berperilaku } \\
\text { bullying }\end{array}$ & & & \\
\hline \multirow{6}{*}{$\begin{array}{l}\text { Dukungan } \\
\text { Sosial }\end{array}$} & \multirow{3}{*}{$\begin{array}{l}\text { Dukungan } \\
\text { Sosial Negatif }\end{array}$} & Count & 12 & 24 & 36 & 0.258 & 0,03 \\
\hline & & Expected Count & 18.8 & 17.2 & 36.0 & & \\
\hline & & $\%$ of Total & $14.0 \%$ & $27.9 \%$ & $41.9 \%$ & & \\
\hline & \multirow{3}{*}{$\begin{array}{l}\text { Dukungan } \\
\text { Sosial Positif }\end{array}$} & Count & 33 & 17 & 50 & & \\
\hline & & Expected Count & 26.2 & 23.8 & 50.0 & & \\
\hline & & \% of Total & $38.4 \%$ & $19.8 \%$ & $58.1 \%$ & & \\
\hline \multirow[t]{3}{*}{ Total } & & Count & 45 & 41 & 86 & & \\
\hline & & Expected Count & 45.0 & 41.0 & 86.0 & & \\
\hline & & \% of Total & $52.3 \%$ & $47.7 \%$ & $100.0 \%$ & & \\
\hline
\end{tabular}

Untuk menguji ada tidaknya perbedaan atau hubungan antar kedua variabel maka dilakukan Analisa bivariat Koefisien koefisien koefisien Crammer's $V$ digunakan untuk menghitung keeratan hubungan antar variabel pada data dan uji hipotesis tentang nilai Odd Ratio (OR) untuk melihat perbedaan risiko antara kelompok terpapar dengan kelompok tidak terpapar. Hasil uji statistik diperoleh nilai $p$ value diperoleh sebersar $0,03(<0,05)$ dan nilai OR sebesar $0.258<1$. Sesuai nilai signifikansi dari uji jika nilai $p \leq \alpha$ dan nilai $\mathrm{OR}<1$, berarti $H o$ ditolak dan faktor tersebut menurunkan risiko atau faktor tersebut memberikan efek pencegahan (Widarsa, et al. 2016). Dengan demikian dapat disimpulkan bahwa terdapat hubungan antara dukungan sosial teman sebaya dengan perilaku bullying, dengan adanya dukungan dari teman sebaya peserta didik di SMA Taruna Andhiga dapat menurunkan resiko terpapar dari perilaku bullying dan memberikan efek pencegahan sebesar 0.258 agar tidak berperilaku bullying.

Hasil ini sesuai dengan penelitian dari Septiyuni, et al, (2018) dimana dalam penelitiannya diperoleh nilai koefisien korelasise besar 0,360 dan nilai $\rho<$ 0,05 artinya kelompok teman sebaya berpengaruh terhadap terjadinya perilaku bullying peserta didik di sekolah. Selanjutnya penelitian dari Puspita. et al, (2018) diperoleh tingkat signifikansi korelasi $p=0,000(p<0,05)$ menunjukkan bahwa terdapat hubungan yang signifikan antara dukungan sosial teman sebaya dengan perundungan atau bullying.

Melihat teori dimana perilaku adalah aksi atau tindakan yang dapat diamati dan dipelajari yang merupakan proses interaksi dari individu dengan lingkungannya sebagai wujud respon dari luar maupun dari dalam dirinya. Respon ini dapat bersifat pasif maupun aktif sesuai pengalaman dan interaksi individu dengan lingkungan terutama pengetahuan dan sikap (King, 2010). Terdapatnya hubungan yang bersifat teloransi yang disertai dengan menolong dan mempunyai penilaian secara khusus bagi setiap individu yang berdasarkan dari sumber yang diberikan 
dan disediakan oleh individu lain untuk mempengaruhi tingkat kemakmuran dan kesejateraan seorang (Taylor. et al, 2009). Dukungan teman sebaya akan memberikan sesorang dalam hidupnya merasa akan mudah dalam menjalankan segala aktivitas dalam kehidupan kerana mendapat perhatian dan penghargaan dari orang yang dekat dengan dirinya. Adanya pergaulan antar teman sebaya akan terjalinnya sebuah ikatan persahabatan antar individu yang dianggap dapat memberikan sebuah kepuasan secara emosional di dalam setiap kehidupan individu. Terdapatnya sebuah sport sosial memperlihatkan korelasi antar interpersonal yang melindungi seorang individu terhadap perilaku negatif, sehingga individu tersebut merasa senang, untuk diperhatikan dan dicintai yang pada akhirnya timbul rasa percaya diri pada individu tersebut. Selain itu, dukungan sosial positif dapat mengatasi tekanan secara psikologis ketika dalam masa atau kondisi sulit yang menekan, misalnya, dengan adanya sebuah dukungan secara sosial dari peserta didik lain yang membantu peserta didik mengatasi berbagai ganngguan salah satunya stres dalam menjalani pendidikan dan pembelajaran di sekolah, membantu memperkuat imun dalam tubuh, mengurangi respon terhadap stres, serta memperkuat fungsi untuk menangkal berbagai penyakit kronis (Lesari, 2016). Sehingga melihat dari hasil data maka perilaku peserta didik di SMA Taruna Andhiga memiliki merespon untuk berinteraksi yang baik dengan temannya dan saling memberikan perhatian dalam ikatan persahabatan.

Teman sebaya memiliki fungsi positif yaitu dapat memberikan kemampuan maupun keterampilan dalam berkomunikasi di bermasyarakat atau sosial, bertambanya penalaran dalam menganalisis berbagai permasalahan, dan terakhir peserta didik belajar untuk mengekspresikan perasan diri kearah yang lebih matang dalam penalaran. Melalui diskusi dan tukar pikiran bersama-sama dengan temanteman sebayanya para remaja dapat mengekspresikan ide-ide keinginanan, perasaan dan memiliki kemampuan dalam pemecahan masalah. Dimana dukungan sosial itu mengacu pada kenyamanan, kepedulian, penghargaan, kesediaan untuk membantu seseorang dari orang-orang lain atau kelompok. Dukungan dapat datang dari banyak orang terkasih, keluarga, para teman, dokter, atau organisasi di masyarakat. Di dalam dukungan sosial, dipengaruhi oleh, dukungan instumental, dukungan emosional, dukungan jaringan secara sosial, dukungan informasi, dan dukungan penghargaan. Tinggi dan rendahnya perilaku bullying dialami peserta didik dalam hal ini remaja yang bersekolah akan terlihat dan dirasakan berdasarkan nilai yang diperoleh ketika sekala dukungan teman sebaya dalam aksi bullying. Baron \& Byrne (2005), menyampaikan bahwa salah satu penyebab remaja melakukan tindakan perilaku bullying kekerasan dikarenakan adanya suatu daya tarik kelompok teman sebaya akibat seseorang merasa memiliki suatu kesamaan dengan anggota kelompok dimana mereka melakukan aksi bullying dikarenakan ikut-ikutan dengan teman dan sebagian mengatakan bahwa membalas kembali perilaku teman yang mem-bully. Hal ini menunjukkan faktor konformitas teman sebaya menjadi penyebab pelajar melakukan bullying kepada temannya.

Berdasarkan kajian ini maka semakin tinggi nilai yang diperoleh peserta didik dalam skala dukungan sosial teman sebaya maka akan semakin tinggi pula dukungan sosial teman sebaya yang diperoleh oleh peserta didik tersebut dalam melakukan bully. Sebaliknya, semakin rendah skor yang diperoleh peserta didik 
pada skala dukungan sosial teman sebaya maka semakin rendah pula dukungan teman sebaya pada peserta didik tersebut untuk melakukan bully. Dukungan teman sebaya yang tinggi akan menyebabkan perilaku bullying akan tinggi. Akan tetapi jika konformitas teman sebaya rendah akan menunjukkan perilaku bullying yang rendah.

Atas dasar studi ini ditemukan bahwa terdapat hubungan dukungan sosial teman sebaya terhadap perilaku bullying di SMA Taruna Andhiga Bogor. Hal tersebut bisa dijadikan acuan oleh pihak sekolah khususnya bagi para guru dan peserta didik agar meminimalkan terjadinya perilaku bullying pada peserta didik dengan diberikan bimbingan konseling secara rutin dan pemasangan poster anti bullying.

\section{KESIMPULAN}

Hasil studi yang dilakukan maka diperoleh kesimpulan berikut: 1) Peserta didik di SMA Taruna Andhiga lebih banyak yang memberikan dukungan secara positif dibandingkan yang negatif; 2) Peserta didik di SMA Taruna Andhiga rmempunyai kecenderungan berperilaku bullying dibandingkan yang tidak berperilaku bullying; 3) Terdapat hubungan antara dukungan sosial teman dengan perilaku bullying; 4) Peserta didk SMA Taruna Andhiga beresiko berperilaku bullying dibandingkan yang tidak mendapat dukungan sosial.

Atas dasar hasil kesimpulan tersebut, terdapat beberapa hal yang dapat disarankan yaitu: 1) Membangun lingkungan sekolah dimana peserta didik dapat bersosialisasi dengan teman-teman di sekitar sekolah, agar memiliki relasi hubungan pertemanan yang baik dan terhindar dari perilaku bullying, serta lebih memilih kegiatan-kegiatan positif, baik di dalam maupun di luar lingkungan sekolah; 2) Sekolah perlu meningkatkan program anti bullying yang tepat bagi peserta didik; dan 3) Diperlukan kajian lebih mendalam tentang perilaku bullying dengan menggunakan variabel lain, seperti lingkungan pendidikan di rumah, konsep diri.

\section{REFERENSI}

Afroz, J. S. H. (2015). Bullying in elementary schools: Its Causes and Effects on Students. Journal of Education and Practice, 5(1). P.43-56. https://files.eric.ed.gov/fulltext/EJ1079521.pdf.

Aisyiah, Y. (2017). Hubungan dukungan sosial teman sebaya dengan problem solving siswa SMP. Jurnal Al-Qalb, Vol. 9, No. 2. p118-126, DOI: https://doi.org/10.15548/alqalb.v8i2.876.

Amalia, E., et al. (2019). Skrining dan edukasi pencegahan bullying pada peserta didik SMA negeri di Kota Mataram. Jurnal Pengabdian Magister Pendidikan IPA, Vol. 2, No.1, p30-35. DOI: 10.29303/jpmpi.v1i2.245.

Baron, R.A. \& Byrne. (2005). Psikologi sosial. Jakarta: Erlangga.

Dara, A.G., et al. (2018). Pengaruh kelompok teman sebaya (Peer Group) terhadap perilaku bullying siswa di sekolah. Jurnal Sosietas, 5(1). p1-4. DOI: https://doi.org/10.17509/ bsosietas.v5i1.1512.

Darmawan, D. (2017). Bullying phenomena in school setting. Jurnal Kependidikan, 1(2). p164-175. DOI: https://doi.org/10.21831/jk.v1i2.9713. 
Darmayanti, K. K. H., Kurniawati, F., \& Situmorang, D. D. B. (2019). Bullying di sekolah: Pengertian, dampak, pembagian dan cara menanggulanginya. Pedagogia: Jurnal IImu Pendidikan, 17(1), 55-66. DOI: 10.17509/ pdgia.v17i1.13980.

Desmita. (2010). Psikologi perkembangan. PT Remaja Rosdakarya: Bandung.

Febri, F. \& Nuristighfari, M.K. (2014). Kelekatan aman, religiusitas, dan kematangan emosi pada remaja. Jurnal Psikologi Integratif, 2 (1). p22-29. DOI: https://doi.org/10.14421/jpsi.2014.

Fenti, D.F. \& Siti N. (2019). Hubungan sikap dengan pengalaman (Bullying) pada peserta didik SMKN 2 Kota Bogor. Hearty, 7(1). p1-8. DOI: http://dx.doi.org/10.32832/hearty.v7i1.2298.

Heryana, M.I. (2019). Fenomena bullying antar siswa. Jurnal Pendidikan IImu Pengetahuan Sosial Indonesia, 4(1), p.25-29. DOI: 10.26737/jpipsi.v4i1. 1237.

Hidayat, A. A. (2007). Metode penelitian keperawatan dan teknik analisa data. Jakarta: Salemba Medika.

Indri, E., \& Layyinah, L. (2016). Effect of sosial competence and school stres on bullying behavior in adolescent. Tazkiya, 4(1). P.1-10. DOI: 10.15408/ tazkiya.v4i1.10824.

Irnie, V. (2017). Mengatasi bullying siswa sekolah dasar dengan menerapkan manajemen kelas yang efektif. Pedagogik, V(1). P.28-41. http://jurnal.unismabekasi.ac.id/index.php/pedagogik /article/view /1273.

Isza, G.S \& Wulanyani N.M.S. (2019). Pengaruh dukungan sosial teman sebaya dan kontrol diri terhadap perundungan (Bullying) pada remaja awal di Denpasar. Jurnal Psikologi Udayana, 6 (1), p182-192. DOI: https://doi.org/ 10.24843/JPU.2019.v06.101.p18.

Kandi, R.D. (2016). Kekerasan di sekolah juga terjadi atas nama ekskul. Jakarta: KPAI.

Karina, K., et al. (2013). Perilaku bullying dan karakter remaja serta kaitannya dengan karakteristik keluarga dan peer group. Jurnal IImu Keluarga dan Konsumen, 2(5). P.20-29. DOI: https://doi.org/10.24156/jikk.2013.6.1.20.

Karnowahadi, K. (2017). Odds ratio: A result of business research analysis. Jurnal Admisi \& Bisnis, 18(1): p.47-54. https://jurnal.polines.ac.id/index.php/ admisi/issue/view/166.

King, L.A. (2010). Psikologi umum sebuah pandangan apresiatif. Jakarta: Salemba Humanika.

Kemenkes. (2014). Situasi kesehatan reproduksi remaja. Info Datin.

Lagmin,G. (2016). Bullying prevention-UNICEF report reveals bullying is a world wide problem. http://www.ungei.org/globalstatusonschoolviolence(1).pdf.

Latifah, F. (2012). Hubungan karakteristik anak usia sekolah dengan kejadian bullying di sekolah dasar X di Bogor. Skripsi. Jakarta: Fakultas IImu Keperawatan Universitas Indonesia. http://lib.ui.ac.id/file?file=digital/ 20313561-S43718-Hubungan\%20karakteristik.pdf.

Lesari, W.S. (2016). Analisis faktor-faktor penyebab bullying di kalangan peserta didik. Sosio Didaktika. Sosial Science Education Journal, 3(2). p.147-157. DOI: http://dx.doi.org/10.15408/sd.v3i2.4385. 
Muthia, A. (2017). Bullying prevention strategies through the "Care school" program for peer facilitator. Asian Journal of Environment, History and Heritage, 1(1). P.211-222. https://pdfs.semanticscholar.org/4c5b/a0a026a11f8904c 49dbc40328b9227a20e38.pdf.

Manesini, E., \& Salmivalli, C. (2017). Bullyingin schools: the state of knowledge and effective interventions. Psychology, Health \& Medicine, 22(15), p.125-138. https://doi.org/10.1080/13548506.2017.1279740.

Nadi, M.A. (2018). Analisa pemilihan moda transportasi umum rute Tanjung Karang-Bandara Radin Inten II dengan stated preference dan uji Crame's V. Borneo engineering: Jurnal Teknik Sipil, 2 (2). 137-147. http://jurnal.borneo.ac.id/index.php/borneoengineering.

Nini, S.W. (2016). Hubungan dukungan sosial teman sebaya dengan kemampuan bersosialisasi pada peserta didik SMK Negeri 3 Medan. Jurnal Diversita, 2(2). P.1-11. Doi: https://doi.org/10.31289/diversita.v2i2.512.

Palettei, A.R., \& Sulfemi, W.B. (2019). Pengaruh kelompok kerja guru (KKG) terhadap peningkatan kompetensi pedagogik dan kemampuan menulis karya ilmiah. Jurnal Pendidikan Dasar Indonesia, 4(20). P.53-58. DOI: http://dx.doi.org/10.26737/jpdi.v4i2.1522.

Paramitasari, R. \& Alfian, I.R. (2012). Hubungan antara kematangan emosi dengan kecenderungan memaafkan pada remaja. Jurnal Psikologi Pendidikan dan Perkembangan, 1 (02). P.170-182. http://journal.unair.ac.id/filerPDF/ 110511131_1v.pdf.

Papacosta, E. S., Paradeisioti, A., \& Lazarou, C.H. (2014). Bullying phenomenon and preventive programs in Cyprus's School System. International Journal of Mental Health Promotion, 16 (1), p.67-80. https://doi.org/10.1080/ 14623730.2014 .888894$.

Pebriansyah, A. (2016). 40 Persen pelajar di Kota Bogor korban bullying. suara.com. https://www.suara.com/news/2016/06/16/034922/40persen pelajardikotabogorkorbanbullying.

Puspita., et al. (2018). hubungan antara dukungan sosial teman sebaya dengan perundungan pada peserta didik SMP PL Domenico Savio Semarang. Jurnal Empati, 7.(4). p.252-259. https://ejournal3.undip.ac.id/index.php/ empati/article/view/23458.

Ribakova, L. A. \&. Valeeva, R. A. (2016). Bullying in school: Case study of prevention and psycho pedagogical correction. International Journal of Environmental \& Science Education, 11(7), p.1603-1617. Doi: $\underline{10.12973 /}$ ijese.2016.366a.

Rokhmatika, L., \& Darminto, E. (2013). Hubungan antara persepsi terhadap dukungan sosial teman sebaya dan konsep diri dengan penyesuaian diri di sekolah pada peserta didik kelas unggulan. Journal Mahasiswa Bimbingan dan Konseling, 01 (01). P.149-157. https://media.neliti.com/medial publications/245518-hubungan-antara-persepsi-terhadap-dukung57dc195c.pdf. 
Sari, P. K., \& Indrawati, E S. (2016). Hubungan Antara Dukungan Sosial Teman Sebaya Dengan Resiliensi Akademik Pada Mahasiswa Tingkat Akhir Jurusan X Fakultas Teknik Universitas Diponegoro, 5 (2). P.177-182. https://ejournal3.undip.ac.id/index.php/empati/article/view/14979.

Saifullah, F. (2016). Hubungan antara konsep diri dengan bullying pada siswa-siswi SMP Negeri 16 Samarinda. eJournal Psikologi, 4 (2). P.200-14. https://ejournal.psikologi.fisip-unmul.ac.id/site/?p=915.

Santrock, J.W. (2012). Life-Spain Development; Perkembangan masa hidup. Jakarta: Erlangga.

Setiawan, A.N. (2015). Pengaruh dukungan sosial teman sebaya terhadap agresivitas peserta didik MAN Yogyakarta. Skripsi. Yogyakarta: Jurusan Pendidikan Islam, Tarbiyah dan Keguruan Universitas Islam Negeri Sunan Kalijaga. http://digilib.uin-suka.ac.id/20398/.

Silalahi, U. (2015). Metode penelitian sosial kuantitatif. Bandung: PT. Refika Aditama.

Saifuddin, A. (2007). Reliabilitas dan validitas. Yogyakarta: Pustaka Pelajar.

Septiyuni, et al. (2018). Pengaruh kelompok teman sebaya (Peer Group) terhadap perilaku bullying siswa di sekolah. Jurnal Sosietas, 5(1). P.1-4. DOI: https://doi.org/10.17509/sosietas.v5i1.1512.

Smet, B. (2006). Psikologi kesehatan. Jakarta: PT .Grasindo.

Smith, P. K. (2013). School bullying. Sociologia, problemas e práticas. Journals Openedition, 71 (1), p.81-98. Doi: http://journals.openedition.org/spp/988.

Sugiyono. (2010). Metode penelitian kuantitatif kualitatif dan R\&D. Bandung: Alfabeta.

Sulfemi, W.B. (2018). Pengaruh disiplin ibadah sholat, lingkungan sekolah, dan intelegensi terhadap hasil belajar peserta didik mata pelajaran pendidikan agama Islam. Edukasi: Jurnal Penelitian Pendidikan Agama dan Keagamaan, 6 (2). 166-178. DOI:10.32729/edukasi.v16i2.474.

Sulfemi, W.B. (2019). Bergaul tanpa harus menyakiti. Bogor: Visi Nusantara Maju.

Sulfemi, W. B. (2019). Model pembelajaran kooperatif mind mapping berbantu audio visual dalam meningkatkan minat, motivasi dan hasil belajar IPS. Jurnal PIPSI (Jurnal Pendidikan IPS Indonesia), 4(1) p.13-19. DOI: http://dx.doi.org/10.26737/jipips.v4i1.1204.

Sulfemi, W.B., \& Yuliana, D. (2019). Penerapan model pembelajaran discovery learning meningkatkan motivasi dan hasil belajar pendidikan kewarganegaraan. Jurnal Rontal Keilmuan Pancasila dan Kewarganegaraan, 5(1). P.17-30. Doi: http://dx.doi.org/10.29100/jr.v5i1. 1021.

Taylor, S.E., et al. (2009). Psikologi Sosial. Ed. 12. Jakarta: Kencana Prenada Media Group.

Widarsa, T., et al. (2016). Modul: Analisis Data Untuk Variabel Outcome Berskala Nominal Dua Kategori (Binary Outcome). Program Studi Kesehatan Masyarakat. Fakultas Kedokteran Universitas Udayana Denpasar,

Yusuf, H., \& Fahrudin, A. (2012). Perilaku bullying: Asesmen multidimensi dan intervensi sosial. Jurnal Psikologi Undip, 11(2), p.1-10. DOl: https://doi.org/10.14710/jpu.11.2.10. 